\title{
PENINGKATAN HASIL BELAJAR IPS DENGAN METODE PEMBELAJARAN LEARNING COMMUNITY DI SMP NEGERI 2 PERCUT SEI TUAN
}

\author{
RAMSES SIMBOLON \\ SMP Negeri 2 Percut Sei Tuan \\ revasandra12345@gmail.com
}

\begin{abstract}
ABSTRAK
Tujuan penelitian ini adalah untuk meningkatkan hasil belajar IPS dengan metode pembelajaran learning community kelas 9-5 SMP Negeri 2 Percut Sei Tuan Tahun ajaran 2018/2019. Penelitian ini adalah penelitian tindakan kelas dengan 2 siklus, setiap siklus terdiri 4 kegiatan yaitu perencanaan, tindakan, observasi dan refleksi yang diikuti oleh perencanaan pada siklus berikutnya dengan memanfaatkan hasil refleksi sebelumnya. Solusinya dirancang berupa penggunaan metode pembelajaran learning community dalam mengajarkan pokok bahasan ketergantungan antar ruang dan pengaruhnya terhadap kesejahteraan masyarakat kelas 9-5 berjumlah 34 orang SMP Negeri 2 Percut Sei Tuan Kab. Deli Serdang Tahun Ajaran 2018/2019. Temuan penelitian menunjukkan pembelajaran ketergantungan antar ruang dan pengaruhnya terhadap kesejahteraan masyarakat dengan penerapan metode pembelajaran learning community dapat meningkatkan hasil belajar siswa dibuktikan dengan meningkatnya hasil belajar IPS setiap siklus yaitu dari rata-rata 64,12 menjadi rata-rata 79,40. Aktivitas siswa berada pada kategori baik
\end{abstract}

Kata Kunci : Hasil Belajar, learning community, IPS

\section{PENDAHULUAN}

Pembelajaran IPS bukan hanya untuk menguasai tentang pengetahuan belaka, tetapi juga untuk mampu menggunakan ilmu yang telah dipelajarinya dan membentuk siswa agar menjadi warga masyarakat yang percaya diri dalam berperan serta secara produktif (Depdiknas, 2000 : 47). pembelajaran IPS memiliki makna penting dalam pembentukan manusia yang produktif. Pembelajaran IPS berkaitan erat dengan kehidupan sehari-hari. Materi IPS umumnya diajarkan dengan metode ceramah, sehingga siswa cenderung lebih cepat lupa pada materi yang telah disampaikan ketika ditanya dua atau tiga hari kemudian. Penyebabnya adalah siswa tidak sepenuhnya menerima materi yang disampaikan oleh guru, karena semua indera manusia tidak terlibat. Seharusnya pembelajaran IPS tidak hanya diajarkan dengan metode ceramah, tetapi bisa bervariasi dengan metode pembelajaran yang konstektual. Karena siswa dalam penerapan metode ceramah hanya akan diajak berimajinasi tanpa bisa merasakan atau melihat keadaan yang sebenarnya

Dalam proses pembelajaran ada kecenderungan guru sangat dominan peranannya, sehingga guru berfungsi sebagai sumber belajar dan pemegang otoritas tertinggi dalam proses pembelajaran ketika berada di depan kelas. Pada proses 
pembelajaran guru mendominasi pembelajaran yang artinya guru aktif murid pasif, guru pada hakekatnya dapat membantu menciptakan situasi yang kondusif dengan memberikan motivasi dan bimbingan agar siswa dapat mengembangkan potensi dan kreativitas melalui kegiatan belajar, dalam proses pembelajaran adalah proses, artinya dalam belajar akan terjadi proses melihat, membuat, mengamati, menyelesaikan masalah atau persoalan, menyimak, dan latihan (Anitah, 2018)

Hasil observasi awal terhadap siswa kelas 9 SMP Negeri 2 Percut Sei Tuan diperoleh nilai IPS masih kategori rendah dimana rata-ratanya di bawah KKM, Berdasarkan penelitian awal ditemukan minat belajar siswa, tanggung jawab siswa dalam melaksanakan tugas - tugas sekolah terbilang rendah. Siswa cenderung diam dan tidak aktif dalam pembelajaran. Hasil belajar 2 tahun terakhir dapat dilihat Tabel. 1 di bawah ini

Tabel : 1 Nilai UAS IPS SMP Negeri 2 Percut Sei Tuan

\begin{tabular}{|c|c|c|c|c|c|}
\hline NO. & $\begin{array}{c}\text { Tahun } \\
\text { Pelajaran }\end{array}$ & $\begin{array}{c}\text { Nilai Kriteria } \\
\text { Ketuntasan } \\
\text { Minimal (KKM) }\end{array}$ & $\begin{array}{c}\text { Nilai } \\
\text { Terendah } \\
(\text { NTR) }\end{array}$ & $\begin{array}{c}\text { Nilai } \\
\text { Tertinggi } \\
\text { (NTT) }\end{array}$ & $\begin{array}{c}\text { Nilai rata- } \\
\text { rata (NRR) }\end{array}$ \\
\hline 1. & $2016 / 2017$ & 75 & 54 & 78 & 62,70 \\
\hline 2. & $2017 / 2018$ & 75 & 22 & 76 & 62,30 \\
\hline
\end{tabular}

Sumber : DKN SMP Negeri 2 Percut Sei Tuan

Rendahnya hasil UAS disebabkan beberapa hal yaitu pada pembelajaran IPS (1) siswa diwajibkan menghafal tanpa mengetahui makna dari materi- materi yang dihafal. (2) tidak adanya interaksi atau komunikasi antar siswa dengan guru, mengakibatkan pembelajaran menjadi pasif yang berakibat kreativitas siswa tidak berkembang. Siswa dibebani dengan tugas- tugas yang sebenarnya mereka sendiri tidak memahami makna itu.

Sudah seharusnya guru merubah cara mengajarnya dengan menggunakan metode pembelajaran yang bervariasi. Metode pembelajaran yang tepat akan membuat siswa termotivasi untuk belajar, yang akan meningkatkan hasil belajar siswa. Hasil belajar itu sendiri merupakan suatu kemampuan yang berrupa keterampilan dan perilaku baru sebagai akibat dari latihan atau pengalaman yang diperoleh. Hasil belajar tersebut berkaitan dengan pencapaian ketiga ranah pendidikan yakni kognitif, afektif dan psikomotorik. Hasil belajar pada seseorang sering tidak langsung tampak tanpa seseorang itu melakukan tindakan untuk memperlihatkan kemampuan yang diperolehnya melalui belajar.Namun demikian, hasil belajar merupakan perubahan yang mengakibatkan orang berubah dalam perilaku, sikap dan kemampuannya. Kemampuan-kemampuan yang menyebabkan perubahan tersebut menjadi kemampuan kognitif yang meliputi pengetahuan dan pemahaman, kemampuan sensori-motorik yang meliputi keterampilan melakukan gerak badan dalam urutan tertentu,dan kemampuan dinamik-afektif yang meliputi sikap dan nilai yang meresapi perilaku dan tindakan. 
Untuk mengatasi permasalahan yang diuraikan di atas diterapkan metode learning community yang ditemukan psikolog Torsten Husen (Husen, 16 ). Aqib (2013) menyatakan Masyarakat belajar (learning community) yaitu sekelompok orang yang terikat dalam kegiatan belajar, bekerja sama dengan orang lain lebih baik daripada belajar sendiri, bertukar pengalaman dan ide. Metode pembelajaran learning community, yaitu berbicara dan berbagi pengalaman dengan orang lain, bekerja sama dengan orang lain untuk menciptakan pembelajaran yang lebih baik dibandingkan dengan belajar sendiri. Siswa benar-benar ditempatkan sebagai subjek belajar. Dengan metode learning community akan menciptakan konsep masyarakat belajar di sekolah, yakni proses belajar membelajarkan antara guru dengan guru, guru dengan siswa, siswa dengan siswa, masyarakat sekolah dengan masyarakat di luar sekolah, agar prestasi belajar siswa dapat ditingkatkan serta dapat menumbuhkan kepedulian antara sesama.

Teknik Learning Community (masyarakat belajar) terfokus pada penerapan kelompok belajar yang homogen dalam proses pembelajaran sehingga terjadi komunikasi dua arah, tidak hanya berkomunikasi antar guru dengan siswa, tapi juga terjadi antar siswa dengan siswa maupun dengan lingkungan sekitar. sehingga terjadi komunikasi dua arah yang menghasilkan pengetahuan dan pengalaman baru.

\section{Kerangka Metode learning community (masyarakat belajar)}

Menurut Kunandar (2007 ) Ada 3 aspek yang perlu diperhatikan dalam Leraning Community. Yaitu

1. Tujuan harus jelas bagi setiap anggota kelompok, agar diperoleh hasil kerja yang baik.

2. Interaksi

Dalam kerja kelompok ada tugas yang harus diselesaikan bersama sehingga perlu dilakukan pembegian kerja

3. Kepemimpinan

Tugas yang jelas, komunikasi yang efektif, kepemimpinan yang baik, akan berpengaruh terhadap suasana kerja, dan pada gilirannya suasana kerja ini akan mempengaruhi proses penilaian tugas.

\section{Langkah-langkah penerapan metode learning community (masyarakat belajar)}

Langkah-lagkah metode Learning Community dalam pembelajaran

1. Membentuk kelompok beranggotakan 4-6 siswa secara heterogen;

2. Guru menyajikan bahan pembelajaran;

3. Guru memberi tugas kepada kelompok untuk dikerjakan oleh anggota kelompok. Anggota yang mengetahui membantu menjelaskan pengetahuannya kepada anggota lain yang belum tahu dalam kelompoknya yang berkopetensi untuk menguasai bahan yang dipelajari. Masing-masing kelompok bertanggung jawab atas anggota kelompoknya;

4. Masing-masing kelompok secara bergiliran mempersentasikan hasilnya;

5. Guru memberi waktu kepada siswa untuk tanya jawab;

6. Guru memberi penilaian kepada siswa pada saat pemberlajaran berlansung; Refleksi terhadap pelajaran yang telah dibahas;

7. Penutup. 
Metode pembelajaran learning community akan menciptakan suasana pembelajaran yang aktif menyenangkan sehingga membuat siswa termotivasi untuk belajar IPS. Materi ketergantungan antar ruang dan pengaruhnya terhadap kesejahteraan masyarakat merupakan materi yang ada dilingkungan sekitar, siswa akan mengalami pengalaman langsung ketika belajar, yang berakibat meningkatnya minat, kraetivitas dan hasil belajar siswa.

\section{METODE PENELITIAN}

Penelitian ini dilaksanakan di SMP 2 Percut Sei Tuan Kabupaten Deli Serdang Provinsi Sumatera Utara. Subjek dalam penelitian ini adalah siswa kelas 9-5 SMP 2 Percut Sei Tuan, Tahun ajaran 2018/2019 yang berjumlah 34 orang terdiri dari 18 siswa perempuan dan 16 siswa laki-laki. Waktu penelitian di mulai dari Minggu kedua Januari 2019 sampai Maret 2019. Penelitian tindakan kelasini dilakukan dengan metode penelitian tindakan kelas yang berlangsung selama 2 siklus. Masing-masing siklus terdiri dari tahapan perencanaan, pelaksanaan, observasi dan refleksi. Metode penelitian yang dilakukan peneliti adalah dengan melaksanakan metode pembelajaran learning community pada pembelajaran IPS

\section{HASIL DAN PEMBAHASAN}

\section{Deskripsi Pra Siklus}

Sebelum melaksanakan tindakan Siklus I, peneliti melakukan tes prasiklus Hasil data pra siklus berupa catatan lapangan mengenai proses pembelajaran Jenis-jenis kegiatan ekonomi, data hasil belajar, lembar observasi dan dokumen dari guru mata pelajaran IPS yang berhubungan dengan pembelajaran IPS di kelas. peneliti mengadakan tindakan perbaikan pada siklus I dan siklus II. Tes yang digunakan dalam prasiklus adalah tes pilihan berganda. tes pilihan berganda digunakan peneliti untuk mengetahui kemampuan siswa dalam proses pembelajaran ketergantungan antar ruang dan pengaruhnya terhadap kesejahteraan masyarakat. Jumlah siswa yang mengikuti tes prasiklus sebanyak 34 siswa. Dari data diatas diperoleh hanya 2 orang siswa yang tuntas, dengan nilai terendah 25, tertinggi 70, rata-rata nilai hasil belajar $\bar{X}=40,44$. Masih jauh dibawah nilai standar KKM. Oleh sebab itu dengan melihat data observasi maka diterapkanlah metode pembelajaran learning community.

\section{Siklus I dan II}

Data siklus I diambil setelah penelitian siklus I dilaksanakan. Pelaksanaan penelitian siklus I sebanyak 2 pertemuan. Pertemuan pertama dilaksanakan pada tanggal 28 Januari 2019 dan pertemuan kedua dilaksankanakan pada tanggal 30 Januari 2019. Siklus II dilaksanakan pada tanggal 11 Februari 2019 dan 13 Februari 2019 2.1. Hasil Belajar

Data Hasil belajar Kelas 9-5 SMP Negeri 2 Percut Sei Tuan siklus I dan II pada mata pelajaran IPS materi ketergantungan antar ruang dan pengaruhnya terhadap kesejahteraan masyarakat pada Tabel 2 dibawah ini 
Tabel : 2 Hasil Belajar IPS Siklus I dan II

\begin{tabular}{|c|c|c|c|}
\hline Hasil Test & Pra Siklus & Siklus I & Siklus II \\
\hline Skor terendah & 20 & 45 & 60 \\
\hline Skor tertinggi & 65 & 80 & 95 \\
\hline Ketuntasan & $2,90 \%$ & $41 \%$ & $88 \%$ \\
\hline Rata-rata & 40,44 & 64,12 & 79,71 \\
\hline
\end{tabular}

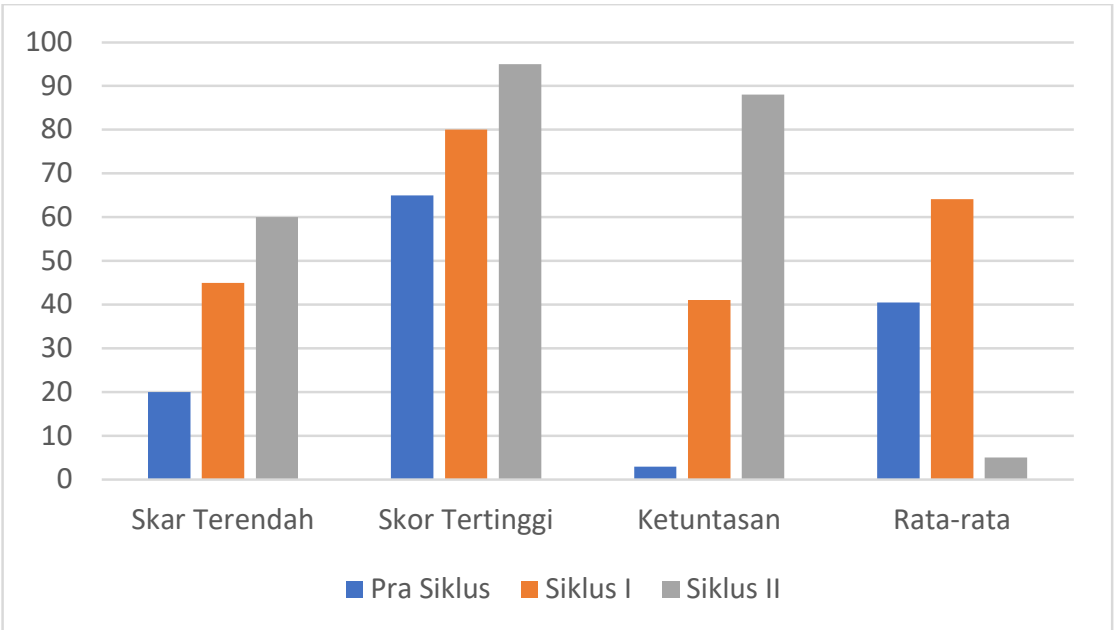

Gambar 1. Diagram Hasil Belajar

Dari Tabel 2 diatas menunjukkan bahwa ada peningkatan hasil belajar dari pra siklus ke siklus I dengan penerapan metode pembelajaran learning community. penguasaan siswa terhadap materi pembelajaran mencapai rata-rata $\bar{X}=64,12$, dengan ketuntasan $41 \%$. Jumlah siswa yang tuntas 18 orang, dan tidak tuntas 24 orang Dari data tersebut terlihat bahwa kemampuan siswa tertinggi mencapai 80,00 dan paling rendah 45,00 .

Hasil belajar dari siklus I ke siklus II mengalami peningkatan dengan penerapan metode pembelajaran learning community. penguasaan siswa terhadap materi pembelajaran mencapai rata-rata $\bar{X}=79,71$, dengan ketuntasan $88 \%$. Jumlah siswa yang tuntas 30 orang, dan tidak tuntas 4 orang Dari data tersebut terlihat bahwa kemampuan siswa tertinggi mencapai 95,00 dan paling rendah 50,00.

\subsection{Data Keaktifan Siswa}

Data hasil observasi mengenai keaktifan siswa dalam mengikuti pembelajaran dengan menggunakan metode pembelajaran learning community adalah sebagai berikut: 
Tabel : 3 Lembar Observasi Aktivitas Siswa

\begin{tabular}{|c|l|c|c|}
\hline No & \multicolumn{1}{|c|}{ Indikator } & Siklus I & Siklus II \\
\hline 1 & $\begin{array}{l}\text { Mempersiapkan diri sebelum } \\
\text { menerima pembelajaran }\end{array}$ & 1,76 & 3,40 \\
\hline 2 & $\begin{array}{l}\text { Memperhatikan penjelasan } \\
\text { dari guru }\end{array}$ & 2,55 & 3,71 \\
\hline 3 & $\begin{array}{l}\text { Menyerap informasi yang } \\
\text { diberikan guru melalui media } \\
\text { pembelajaran }\end{array}$ & 2,48 & 3,62 \\
\hline 4 & $\begin{array}{l}\text { berdiskusi dengan } \\
\text { kelompoknya. }\end{array}$ & 2,12 & 3,29 \\
\hline 5 & $\begin{array}{l}\text { Siswa mempresentasikan hasil } \\
\text { diskusi }\end{array}$ & 1,76 & 3,24 \\
\hline 6 & Membuat Kesimpulan & 2,24 & 3,10 \\
\hline & Total Perolehan & 12,90 & Cukup \\
\hline & Kategori & & Baik \\
\hline
\end{tabular}

Dari tabel 3 dapat dijelaskan bahwa aktivitas siswa selama pelaksanaan siklus 1 pertemuan I,II menunjukkan hasil yang cukup. Hal tersebut dapat dilihat dari jumlah rata-rata dari skor yang diperoleh yaitu 12,90 dimana angka tersebut termasuk dalam kategori cukup. Aktivitas siswa selama pelaksanaan siklus 1I pertemuan I,II menunjukkan hasil yang baik. Hal tersebut dapat dilihat dari jumlah rata-rata dari skor yang diperoleh yaitu 20,36 dimana angka tersebut termasuk dalam kategori baik

Berdasarkan hasil data terjadi peningkatan hasil belajar tetapi belum optimal, kelemahan mendasar yang ditemukan adalah masih kurangnya waktu yang ditetapkan dalam pelaksanaan pembelajaran, apalagi sebagian waktu latihan yang dimanfaatkan untuk mendemonstrasikan penggunaan strategi pembelajaran. Pada siklus kedua ini, hampir secara keseluruhan permasalahan yang dihadapi siswa telah dapat diatasi dengan baik.

\section{PEMBAHASAN}

\section{Pra Siklus}

Nilai pada tes prasiklus digunakan peneliti untuk mengetahui kelemahankelemahan siswa dalam proses pembelajaran. Setelah peneliti mengetahui kelemahankelamahan siswa, Data hasil belajar tersebut kemudian dianalisis, dan ditemukan suatu permasalahan di dalam pembelajaran IPS yaitu hasil belajar IPS masih rendah. Guru masih mengajar dengan metode ceramah belum menggunakan variasi pembelajaran. Siswa masih kekurangan literatur dalam belajar. Interaksi antara siswa dan guru tidak ada, guru sepenuhnya mendemonasi pembelajaran, sehingga siswa tidak tertarik untuk belajar. 


\section{Siklus I}

Kegiatan pembelajaran dapat menjadi efektif apabila tujuan yang telah ditetapkan dapat tercapai dengan baik. Dengan demikian pembelajaran IPS dapat dikatakan efektif apabila tujuan pembelajaranjuga telah dicapai dengan baik. Pembelajaran secara bermakna dimaksudkan agar efektivitas pembelajaran tercapai, karena dengan pembelajaran yang bermakna sangat dimungkinkan terjadinya transfer belajar melalui pemahaman.

Pembelajaran IPS materi ketergantungan antar ruang dan pengaruhnya terhadap kesejahteraan masyarakat dengan metode pembelajaran learning community merupakan salah satu cara yang efektif untuk meningkatkan aktivitas belajar siswa . Metode pembelajaran learning community membuat murid lebih antusias, aktif, dan saling membantu sesama murid di dalam kelompok belajar. Suasana pembelajaran lebih menyenangkan karena guru tidak sepenunya mendemonasi pembelajaran. Siswa di beri kesempatan untuk mengembangkan kreativitasnya. Pada saat diskusi dan persentase siswa masih terlihat canggung, dan takut mengeluarkan pendapatnya. Siswa masih pasif juga kerika diberi tugas untuk terlibat langsung ke pabrik dan mewancarai karyawan pabrik. Hal ini menjadi salah satu permasalahan yang dihadapi siswa dan guru, literatur juga masih kurang

\section{Siklus II}

Dari hasil observasi dan juga hasil wawancara guru IPS, guru tdak lagi dominan dalam pembelajaran, tetapi hanya mengarahkan siswa, dan mengatasi kesulitan yang dihadapi siswa selama pembelajaran dengan pembelajaran learning community. Hal ini terlihat pada saat proses belajar mengajar berlangsung siswa dengan leluasa dan menyenangkan mengeluarkan pendapatnya kepada sesama kawan baik sesama kelompok, antara kelompok maupun kepada guru yang mengajar. Siswa juga ketika persentasikan hasil kerja kelompoknya tidak lagi canggung tapi sudah berani mengeluarkan pendapatnya.

Prestasi belajar siswa yang ditunjukkan dengan hasil belajar siswa, Penguasaan konsep, keterampilan berpikir kreatif dan keterampilan proses disemua kelompok kemampuan meningkat secara merata. Artinya metode pembelajaran learning community memberikan pengaruh yang sama untuk semua kelompok kemampuan dalam meningkatkan prestasi belajar siswa.

Penerapan metode Learning Community ini sangat cocok digunakan dalam pembelajaran didalam kelas, siswa belajar kelompok dengan teman sekelasnya sendiri dan salah satu temannya yang belum bisa dikasih tahu siswa yang sudah pintar dalam pembelajaran ini. Pada umumnya pembelajaran kelompok lebih baik daripada belajar sendiri. Belajar kelompok membuat siswa semangat belajar dan saling berinteraksi antara siswa dengan siswa lainnya, guru juga harus membimbing anak didiknya supaya pembelajaran kelompok bias berjalan dengan baik dan benar agar nanti siswanya bisa pintar semua. Learning Community juga merupakan bagian terpenting dari kegiatankegiatan aktif. Karena ini penting untuk membentuk kelompok secara cepat dan efisien pada saat bersamaan, memvariasikan komposisi Serta besaran kelompok di dalam kelas. 


\section{SIMPULAN DAN SARAN}

\section{A. Kesimpulan}

Berdasarkan hasil penelitian, dan pembahasan maka dapat diperoleh beberapa kesimpulan sebagai berikut:

1. Penerapan metode pembelajaran learning community ini sangat cocok digunakan dalam pembelajaran didalam kelas khususnya pada pembelajaran IPS karena dapat meningkatkan hasil belajar IPS siswa SMP Negeri 2 Percut Sei Tuan

2. Aktivitas siswa pada penelitian tindakan kelas ini meningkat siswa aktif dalam pembelajaran

\section{B. Saran Tindak Lanjut}

1. Penerapan metode pembelajaran learning community ini sangat cocok digunakan dalam pembelajaran didalam kelas dan sesuai dengan karakteristik siswa dan karakteristik mata pelajaran dan mempengaruhi hasil belajar siswa

2. Perlu dikembangkan metode pembelajaran sejenis, khususnya untuk pembelajaran IPS di SMP

\section{DAFTAR PUSTAKA}

Anitah W., Sri. (2018). Materi Pokok Strategi Pembelajaran di SD. Tangerang Selatan : Universitas Terbuka

Bloom, B.S., (1952). Taksonomi of Education Objectives Book I Cognitif Domain, London. Longman Group Ltd. Tesis Venila Sipayung Pascasarjana

Dimyati dan Mudjiono. 1999. Belajar Dan Pembelajaran. Jakarta: Rineka Cipta. Daryanto 2013. , Inovasi Pembelajaran Efektif, Yrama Widya : Bandung Kunandar. 2007. Guru Profesional Implementasi Kurikulum Tingkat Satuanpendidikan (Ktsp)dan persiapan. PT Raja Grafindo Persada : Jakarta.

Made Pidarta. 2007. Landasan Kependidikan, (akarta: PT Rineka Cipta,

Rusman, 2012. Model-model Pembelajaran (mengembangkan profesionalisme guru), PT Raja Grafindo Persada : Jakarta

Sardjijo dan Ischac. 2017. Pendidikan IPS di SD. Tangerang Selatan : Universitas Terbuka

Trianto. 2010. Mendesain Model Pembelajaran Inovatif Progresif Konsep, Landasan dan Implementasinya pada Kurikulum Tingkat Satuan Pendidikan. Jakarta : Kencana Prenada Group

Wardani, et.al. 2019. Pemantapan Kemampuan Profesional (PKP) - PGSD. Tangerang Selatan : Universitas Terbuka 